\title{
The Response of Duckweed (Lemna minor L.) Roots to Cd and Its Chemical Forms
}

\author{
Yan Xue $\mathbb{D}^{1,2}$ Jin-qin Wang, ${ }^{3}$ Jin Huang, ${ }^{3,4}$ Feng-ying Li, ${ }^{2}$ and Ming Wang ${ }^{1,2}$ \\ ${ }^{1}$ School of Environmental Science and Engineering, Nanjing University of Information Science \& Technology, Nanjing 210044, China \\ ${ }^{2}$ Collaborative Innovation Center of Atmospheric Environment and Equipment Technology, Nanjing 210044, China \\ ${ }^{3}$ School of Applied Meteorology, Nanjing University of Information Science \& Technology, Nanjing 210044, China \\ ${ }^{4}$ Jiangsu Key Laboratory of Atmospheric Environment Monitoring and Pollution Control, Nanjing 210044, China \\ Correspondence should be addressed to Yan Xue; xueyan@nuist.edu.cn
}

Received 28 November 2017; Revised 8 January 2018; Accepted 21 January 2018; Published 15 February 2018

Academic Editor: Peng Wang

Copyright (c) 2018 Yan Xue et al. This is an open access article distributed under the Creative Commons Attribution License, which permits unrestricted use, distribution, and reproduction in any medium, provided the original work is properly cited.

\begin{abstract}
The response of duckweed (Lemna minor L.) roots to $\mathrm{Cd}$ and its chemical forms was investigated. The relative root growth rate and concentrations of $\mathrm{Cd}$ and its different chemical forms in the root, that is, ethanol-extractable $\left(\mathrm{F}_{\mathrm{E}}-\mathrm{Cd}\right), \mathrm{HCl}-\mathrm{extractable}\left(\mathrm{F}_{\mathrm{HCl}}{ }^{-}\right.$ $\mathrm{Cd})$, and residual fractions $\left(\mathrm{F}_{\mathrm{r}}-\mathrm{Cd}\right)$, were quantified. Weibull model was used to unravel the regression between the relative root elongation (RRL) with chemical forms of Cd. Parameters assessed catalase (CAT), peroxidases (POD), and superoxide dismutase (SOD), as well as malondialdehyde (MDA) and total antioxidant capacity (A-TOC). Our results show that both the relative root growth rate and relative frond number were affected by $\mathrm{Cd}$ concentrations. The chemical forms of Cd were influenced by $\mathrm{Cd}$ content in the medium. Relative root elongation (RRL) showed a significant correlation with chemical forms of Cd. Additionally, POD and SOD increased at lower Cd concentrations followed by a decrease at higher Cd concentrations (at more than $5 \mu \mathrm{M} \mathrm{Cd}$ ). Moreover, MDA and A-TOC increased and CAT decreased with increasing Cd exposure. Furthermore, CAT showed a significant correlation with $\mathrm{F}_{\mathrm{HCl}^{-}} \mathrm{Cd}$. Taken together, it can be concluded that the chemical forms of $\mathrm{Cd}$ are statistically significant predictors of Cd toxicity to duckweed and to the other similar aquatic plants.
\end{abstract}

\section{Introduction}

Cadmium (Cd) is a major contributor to heavy metal pollution. It is found in both natural and waste waters and is produced by agriculture through pesticides and fertilizers use and wastewater irrigation and by industry through smelting, metalworking, and pigmentation $[1,2]$. The metal has a relatively high solubility and mobility in water and then is easily absorbed for aquatic plants [3]. It destroys photosynthetic apparatus and carbohydrate metabolisms of plants [3-5] and can be transferred in the food chain to threat human health [6]. Some evidences also indicated that the presence of $\mathrm{Cd}$ affected cell wall construction and vesicular trafficking [7]. Plants have developed several detoxification mechanisms to alleviate $\mathrm{Cd}$ toxicity, including the existence of different forms of metals and sequestration into the cell wall $[8,9]$.

The chemical form of $\mathrm{Cd}$ determines the characteristics of Cd migration, potential phytotoxicity, and accumulation in plants and then influences the detoxification and tolerance to Cd of plants [10-13]. Yin et al. [12] found that the different capacity to binding $\mathrm{Cd}$ different forms (such as $\mathrm{F}_{\mathrm{HCl}^{-}} \mathrm{Cd}$ and $\mathrm{F}_{\mathrm{r}}$-Cd) played an important role in the genotype difference in Cd accumulation of spinach. Mwamba et al. [14] demonstrated that metals which are both in the form of insoluble phosphate and firmly adsorbed in the cell walls and vacuoles are not free to migrate and have low toxicity, whereas $\mathrm{Xu}$ et al. [15] reported that high Cd mobility is often in the forms of the water soluble $\mathrm{Cd}$, inorganic $\mathrm{Cd}$, and $\mathrm{Cd}$ complexes with organic acids. Wang et al. [9], in a comparison of watercress genotypes with low- and high Cd-accumulation, found that low-Cd genotypes may convert $\mathrm{Cd}$ into pectate/proteinbound forms and insoluble phosphate precipitates to a greater degree than high Cd types, and that this could be the primary method by which Cd toxicity and mobility are reduced in watercress. 
Cd has previously been shown to induce reactive oxygen species (ROS) and cause oxidative stress (OS), which damages cell structure and function [16, 17]. Plants have evolved effective scavenging mechanisms to survive the Cd stress [6]. The key components of the ROS-scavenging system are mainly antioxidative enzymes, such as peroxidases (POD), superoxide dismutase (SOD), and catalase (CAT) and also other metabolites, including reduced glutathione, malondialdehyde (MDA), and ascorbic acid [18]. Several studies have found that enzyme activity can be modified by $\mathrm{Cd}$ stress before symptoms of toxicity become visible [19]. Considering this, it is inferred that enzymatic activity may signal this biological process and be an indicator of metal toxicity.

Duckweed (Lemna minor L.) is a small floating aquatic plant consisting of submerged greenish roots and floating plant bodies (referred to as fronds). In terms of its reproduction, this primarily takes place in a vegetative way through the creation of colonies [20]. To be specific, this involves the formation of daughter fronds at the proximal ends of mother fronds in two meristematic regions (ibid). It is well known that duckweed accumulates heavy metals [21], including Cd $[2,22]$. Its physiological response to heavy metal stress [23] has been extensively studied in recent years, and researchers have started to examine its defence mechanisms against heavy metal toxicity [24]. However, relatively few studies have examined the correlation between the heavy metal toxicity (which results from the chemical forms) and antioxidant enzymatic activity in duckweed. This knowledge gap greatly restricts our capability to understand the potential mechanisms of defence against heavy metal toxicity of aquatic plants.

In the present study, an experimental design was developed to achieve the following objectives: firstly, to investigate root growth and the antioxidative enzymatic activity (specifically with respect to CAT, SOD, POD, and MDA) of duckweed roots exposed to different $\mathrm{Cd}$ concentration; secondly, to detect the change of different chemical forms of $\mathrm{Cd}$; and thirdly, to quantify the relationship between the antioxidant system and different chemical forms of $\mathrm{Cd}$, which directly reflect different toxicity of different chemical forms. The achievement of these objectives was planned to illuminate the role of chemical forms in detoxification of aquatic plants to heavy metal.

\section{Materials and Methods}

2.1. Plant Materials and Culture. Sample duckweed seedlings were collected from Yileen Garden in Nanjing, China. The samples were placed in a Hoagland culture solution containing $600 \mu \mathrm{M} \mathrm{Ca}\left(\mathrm{NO}_{3}\right)_{2}, 300 \mu \mathrm{M} \mathrm{MgSO}, 300 \mu \mathrm{M} \mathrm{K}_{2} \mathrm{HPO}_{4}$, $13.8 \mu \mathrm{M} \mathrm{H}_{3} \mathrm{BO}_{3}, 217 \mu \mathrm{M} \mathrm{MnSO}_{4}, 0.3 \mu \mathrm{M} \mathrm{Na}_{2} \mathrm{MoO}_{4}, 0.5 \mu \mathrm{M}$ $\mathrm{CuSO}_{4}, 16.5 \mu \mathrm{M} \mathrm{Fe}(\mathrm{III})-\mathrm{EDTA}$, and $0.3 \mu \mathrm{M} \mathrm{ZnSO}$ under natural light conditions in a greenhouse. The $\mathrm{pH}$ of the medium was taken to 5.5 with $0.1 \mathrm{M} \mathrm{NaOH}$ and $\mathrm{HCl}$. The medium was replaced every other day. Inoculation of a single 2-3 frond colony was used to initiate experimental cultures for growth measurement and of 10-12 colonies for other analyses.
2.2. Toxicity Experiments. Duckweed plants of similar fronds numbers were selected to place in medium containing $\mathrm{Cd}$ $\left(0.1,0.5,1,5,10\right.$, or $\left.20 \mu \mathrm{M} \mathrm{CdCl}_{2}\right)$. A free Cd treatment (only containing Hoagland medium) was used for control. Each treatment was performed in triplicate. The treatment medium was replaced every other day, and the fresh plant samples were collected after 4 days of treatment. Growth over 4 days was monitored by counting the number of fronds, which were recorded as relative frond numbers after Ensley et al. [25].

To calculate relative root elongation (RRL), the formula $\mathrm{RRL}(\%)=100\left(\mathrm{RL}_{\mathrm{T}}-\mathrm{RL}_{\mathrm{S}}\right) /\left(\mathrm{RL}_{\mathrm{C}}-\mathrm{RL}_{\mathrm{S}}\right)$ was applied, where $\mathrm{RL}_{\mathrm{T}}$ is the mean root length (RL), where toxicants (i.e., $\mathrm{Cd}^{2+}$ ) are present, $\mathrm{RL}_{\mathrm{C}}$ is $\mathrm{RL}$ in a toxicant-free control, and $\mathrm{RL}_{S}$ is $\mathrm{RL}$ when the seedling was transferred into the test media. The growth thus quantified can be plotted against toxicant intensity $(T)$ measures such as the overall $\mathrm{Cd}$ concentration and its different chemical forms. The results often plot as negatively sigmoidal curves, which have been characterised with a Weibull equation $[26,27]$. If $T$ limits growth, RRL = $100 / \exp \left[(a T)^{b}\right]$, where $b$ is a shape coefficient and the strength coefficient $a$ increases with the degree of metal toxicity.

2.3. Extraction of Chemical Forms of $C d$. The chemical forms of $\mathrm{Cd}$ were determined using a modified version of the following method described by $\mathrm{Wu}$ et al. [28]. Cd in its different chemical forms was sequentially extracted as shown below:

(i) $80 \%(\mathrm{v} / \mathrm{v})$ ethanol, extracting soluble $\mathrm{Cd}$, including chloride, nitrate, and aminophenol cadmium $\left(\mathrm{F}_{\mathrm{E}^{-}}\right.$ Cd),

(ii) $0.6 \mathrm{M} \mathrm{HCl}$, extracting insoluble $\mathrm{CdHPO}_{4}$ and $\mathrm{Cd}_{3}\left(\mathrm{PO}_{4}\right)_{2}$, other $\mathrm{Cd}$-phosphate complexes and $\mathrm{Cd}$ integrated with pectates and protein, and so on $\left(\mathrm{F}_{\mathrm{HCl}}-\mathrm{Cd}\right)$,

(iii) $\mathrm{Cd}$ in residues $\left(\mathrm{F}_{\mathrm{r}}-\mathrm{Cd}\right)$.

Fresh duckweed root samples were rinsed in tap water and deionized water and then dried with paper tissue. Roots were cut into $1-2 \mathrm{~mm}^{2}$ pieces, which were used separately in the sequential extraction for various forms of Cd. A plant sample of $4 \mathrm{~g}$ was placed in a $50 \mathrm{ml}$ centrifugal tube with $25 \mathrm{ml}$ extractant $\left(80 \%\right.$ ethanol). The tube was kept in a $30^{\circ} \mathrm{C}$ water bath for $18 \mathrm{hrs}$. After the tube was centrifuged for $10 \mathrm{~min}$ at $10000 \mathrm{rpm}$, the supernatant was collected. Another $20 \mathrm{ml}$ of the same extractant was added to the extract for $2 \mathrm{~h}$, and the supernatant was collected and mixed with the previous supernatant collection. The entire extraction solution was collected, evaporated to a constant weight, and then digested using $\mathrm{HNO}_{3}-\mathrm{HClO}_{4}(3: 1, \mathrm{v} / \mathrm{v})$. After one extraction solution had been collected, the next was added to the plant materials still in the beaker using identical procedures. To determine the $\mathrm{Cd}$ content in residues, $\mathrm{HNO}_{3}-\mathrm{HClO}_{4}(3: 1, \mathrm{v} / \mathrm{v})$ was used to digest the plant material after the sequential extraction. Atomic absorption spectrophotometry (TAS-986, Beijing, China) was used to determine the concentrations of the different chemical forms of $\mathrm{Cd}$. 
2.4. Determination of Antioxidative Enzyme Activities. $5.0 \mathrm{ml}$ of extraction buffer solution $\left(0.05 \mathrm{M} \mathrm{NaH}_{2} \mathrm{PO}_{4}+\mathrm{Na}_{2} \mathrm{HPO}_{4}\right.$, $\mathrm{pH}$ 7.4) was used to homogenize $0.5 \mathrm{~g}$ samples of fresh root material. The resulting homogenate was spun in a centrifuge at $10000 \mathrm{~g}$ for $10 \mathrm{~min}$. The procedures were all performed at $4^{\circ} \mathrm{C}$. The supernatant was utilized for the enzyme activity assays. The increase in $470 \mathrm{~nm}$ absorbency as a result of guaiacol oxidation was used to measure POD [29, 30]. To measure the guaiacol-dependent activity of peroxidase, a reaction mixture containing $50 \mathrm{mmol} / \mathrm{l}$ phosphate buffer $(\mathrm{pH}$ 7.0), $10 \mathrm{mmol} / \mathrm{L} \mathrm{H}_{2} \mathrm{O}_{2}, 50 \mathrm{mM}$ guaiacol, and enzyme was used. Assay of SOD was based on its inhibition of photochemical reduction in nitro blue tetrazolium [31]. The reaction mixture was made up of $50 \mathrm{mM}$ phosphate buffer ( $\mathrm{pH} 7.4$ ), $75 \mathrm{mM}$ nitro blue tetrazolium, $13 \mathrm{mM}$ methionine, $100 \mathrm{nM}$ EDTA, $0-200 \mu \mathrm{L}$ of enzyme extract, and $2 \mathrm{mM}$ riboflavin, with the riboflavin being the last to be added. The absorbance of this mixture was read at $560 \mathrm{~nm}$ to measure SOD. One unit of SOD activity (U) was defined as the amount of enzyme that caused $50 \%$ inhibition of the initial reaction rate in the absence of enzyme. The total activity of SOD was given as $\mathrm{U} / \mathrm{mg}$ protein. The method of Aebi [32] was used to measure CAT. This method uses decreasing absorbency at $240 \mathrm{~nm}$ as an indicator of $\mathrm{H}_{2} \mathrm{O}_{2}$ hydrolysis. One unit of enzyme activity (U) was equated for the reduction of 0.1 units at $A_{240}$ in $1 \mathrm{~min}$, and the activity of CAT was expressed in terms of U/mg protein.

2.5. Lipid Peroxidation. The formation of MDA was used as an indirect method to estimate lipid peroxidation in vitro, as this is a by-product of the peroxidation of lipids and reacts with thiobarbituric acid [33]. This was performed through homogenization of $100 \mathrm{mg}$ of fresh plant material in $1 \mathrm{ml}$ of $15 \%(\mathrm{w} / \mathrm{v})$ trichloroacetic acid, $0.25 \mathrm{M} \mathrm{HCl}, 0.37 \%(\mathrm{w} / \mathrm{v})$ 2-thiobarbituric acid, and $0.01 \%(\mathrm{w} / \mathrm{v})$ butylated hydroxytoluene in a ceramic mortar, followed by incubation of the samples for $30 \mathrm{~min}$ at $90^{\circ} \mathrm{C}$, chilling with ice, and, finally, centrifuging for $10 \mathrm{~min}$ at $10000 \mathrm{rpm}$ at $4^{\circ} \mathrm{C}$. The $535 \mathrm{~nm}$ and $600 \mathrm{~nm}$ absorbances of the resulting chromophore were then measured. As a nonspecific turbidity correction, the latter absorbance was subtracted from the former. An extinction coefficient of $156 \mathrm{mM}^{-1} \mathrm{~cm}^{-1}$ was then used to calculate the concentration of MDA.

2.6. Determination of Total Antioxidant Potential. Both enzymatic and nonenzymatic reactions (e.g., SOD, GSH, GSHPX, CAT, VC, and VE) are included in the T-AOC of the protective system. Commercial assay kits from the Nanjing JianCheng Institute, China, were used to measure T-AOC [34] in accordance with the manufacturer's instructions. To summarise, the analysis was a colorimetric assay based on the reduction of $\mathrm{Fe}^{3+}$ to $\mathrm{Fe}^{2+}$ by the antioxidant and the formation of complexes through the reaction of the $\mathrm{Fe}^{2+}$ with the phenanthroline. An absorbance measurement was made at $520 \mathrm{~nm}$, and one unit of antioxidant capacity (U) was characterised as an increase of 0.01 units at $A_{520}$ in $1 \mathrm{~min} / \mathrm{mg}$ protein. T-AOC was expressed in terms of $\mathrm{U} / \mathrm{mg}$ protein.

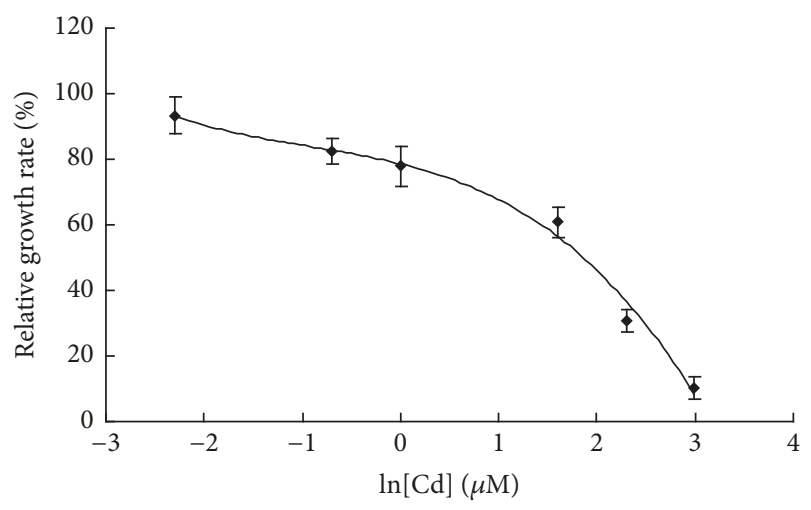

FIGURE 1: Relative root growth rate (\%) as a function of the solution's Cd concentration $(\mu \mathrm{M})$.

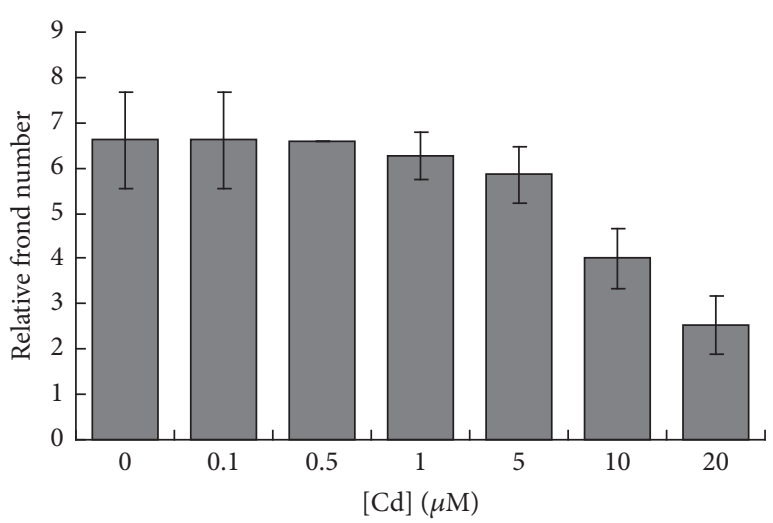

Figure 2: Growth of duckweed during cultivation in medium containing various concentrations of $\mathrm{Cd}(\mu \mathrm{M})$.

2.7. Statistical Analysis. EXCEL 2007 was used for determining the correlation between chemical forms of $\mathrm{Cd}$ and toxic response in the data. A one-way ANOVA with a least significant difference (LSD) test was used to identify significant differences, using a confidence level of $95 \%(P<0.05)$. Spss was used for the ANOVA analysis.

\section{Results}

3.1. Effect of Cd on Duckweed Root Elongation and Frond Numbers. Figure 1 shows that the relative root growth rate was significantly related to $\mathrm{Cd}$ concentration. The relative root growth rate showed a continuous decrease with an increase of exposed Cd concentrations from $0.1 \mu \mathrm{M}$ to $20 \mu \mathrm{M}$. Critical values corresponding to a $50 \%$ reduction of the relative root growth rate were about $10 \mu \mathrm{M}$.

It is important to recognize the fact that the relative frond number was also affected by the $\mathrm{Cd}$ concentration. Figure 2 indicates that the relative frond number, expressing the growth of Cd-exposed duckweed plants, significantly decreased $(P<0.05)$. As the solution's Cd concentration rose, the frond numbers dropped progressively. The relative frond number was $60.7 \%$ lower than that of the control in the solution with a $10-\mu \mathrm{M} \mathrm{Cd}$ concentration. The relative frond 


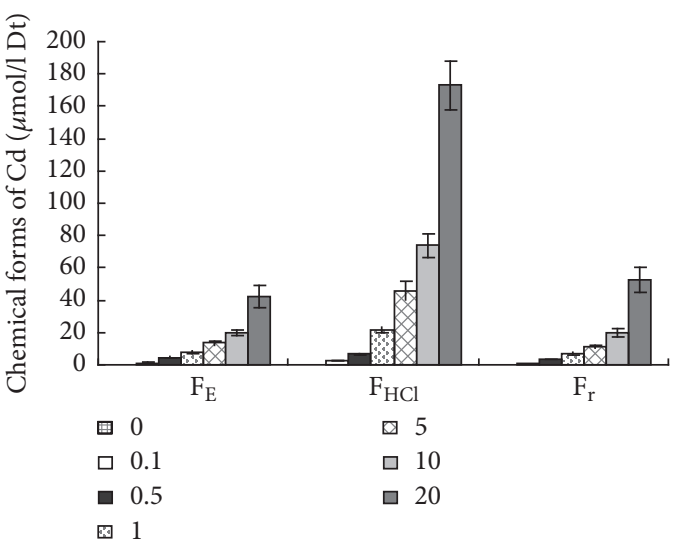

(a)

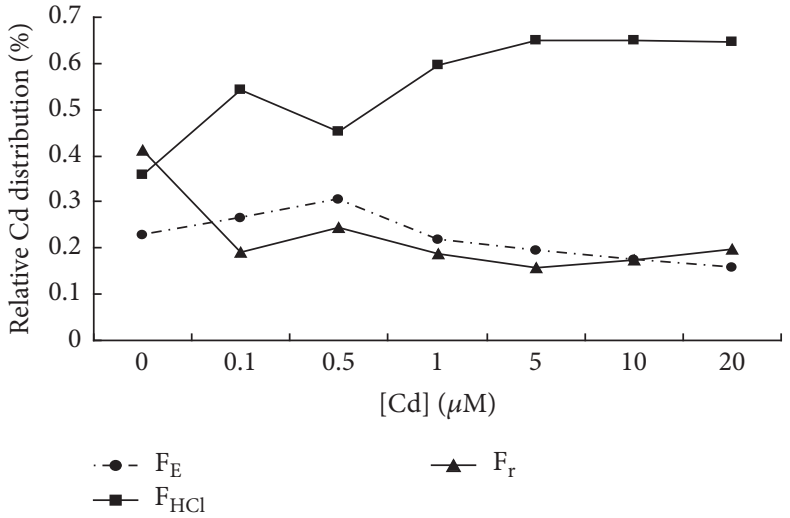

(b)

FIgURE 3: Chemical forms of Cd in duckweed roots (a) and percentage (b) after a 4-day period of exposure to Cd stress.

number dropped to $38.2 \%$ when plants were cultivated using a $20 \mu \mathrm{M}$ Cd concentration medium.

3.2. Chemical Forms of Cadmium in Duckweed Root. The results of chemical forms of $\mathrm{Cd}$ and their relative distribution in duckweed were shown in Figure 3. It was found that $\mathrm{Cd}$ concentrations bound to different chemical forms in duckweed root increased with an increase of Cd exposure concentrations. For example, when the solution's Cd concentration was $0.1 \mu \mathrm{M}$, the $\mathrm{F}_{\mathrm{E}}-\mathrm{Cd}$ and $\mathrm{F}_{\mathrm{HCl}^{-}}-\mathrm{Cd}$ contents were 1.22 and $2.51 \mathrm{mg} / \mathrm{kg}$ root, respectively, and these levels increased significantly for duckweed cultivated in $20 \mu \mathrm{M} \mathrm{Cd}$ solution, reaching 42.13 and $172.9 \mathrm{mg} / \mathrm{kg}$ root, respectively. When the solution's Cd concentrations were in the range of $0.1-10 \mu \mathrm{M}, \mathrm{F}_{\mathrm{HCl}}-\mathrm{Cd}$ was the major chemical form, followed by $\mathrm{F}_{\mathrm{E}}-\mathrm{Cd}$, and finally $\mathrm{F}_{\mathrm{r}}-\mathrm{Cd}$. After exposure to the $20 \mu \mathrm{M} \mathrm{Cd}$ concentration solution, the least prevalent form was $\mathrm{F}_{\mathrm{E}}-\mathrm{Cd}$. The relative distribution varied in a concentration-dependent manner with $\mathrm{Cd}$ treatment. When the $\mathrm{Cd}$ concentration of the solution was $0.5 \mu \mathrm{M}$, the relative distribution of both $\mathrm{F}_{\mathrm{E}}$ and $\mathrm{F}_{\mathrm{r}}$ showed a peak, whereas $\mathrm{F}_{\mathrm{HCl}^{-}} \mathrm{Cd}$ was relatively low. However, when $\mathrm{Cd}$ concentration in the solution increased from $0.1 \mu \mathrm{M}$ to $20 \mu \mathrm{M}$, the relative distribution of $\mathrm{F}_{\mathrm{E}}-\mathrm{Cd}$ and $\mathrm{F}_{\mathrm{r}}-\mathrm{Cd}$ decreased, while the relative distribution of $\mathrm{F}_{\mathrm{HCl}^{-}}-\mathrm{Cd}$ increased. For instance, the percentage decrease for $\mathrm{F}_{\mathrm{E}}-\mathrm{Cd}$ was from $26.5 \%$ to $16.7 \%$ (except $30.3 \%$ at $0.5 \mu \mathrm{M}$ ), whereas the percentage increase for $\mathrm{F}_{\mathrm{HCl}}$-Cd was from $54.4 \%$ to $64.5 \%$ (except $45.3 \%$ at $0.5 \mu \mathrm{M}$ ) (Figure 3(b)).

Figure 4 illustrated the regression results between RRL and $\mathrm{F}_{\mathrm{E}}-\mathrm{Cd}, \mathrm{F}_{\mathrm{HCl}}-\mathrm{Cd}$, and $\mathrm{F}_{\mathrm{r}}-\mathrm{Cd}$. The data indicated that the relationships conformed to the Weibull model, in which the values of $R^{2}$ were above 0.96 .

3.3. Effect of Cd on Antioxidant Enzyme Activity. The responses of the antioxidant enzymes to Cd stress were shown in Figure 5. The relative specific activities of SOD and POD increased at lower $\mathrm{Cd}$ concentrations until they reached a peak, before decreasing at higher concentrations. Both SOD and POD peaked at $5 \mu \mathrm{M}$. The most pronounced 2.67 -fold increase of relative specific enzyme activity was measured for SOD, and this occurred when the plants were exposed to the solution with $5 \mu \mathrm{M} \mathrm{Cd}$ concentration. The peak value of POD was $162.0 \pm 30.7 \%$ (compared to control, $P<0.01$ ) at the concentration of $5 \mu \mathrm{M}$. At higher $\mathrm{Cd}$ concentrations, enzymatic activity decreased significantly and was below the control level reaching $85.2 \pm 8.1 \%$ of the control value, where the concentration of $20 \mu \mathrm{M} \mathrm{Cd}$ was used. However, the activity of SOD was always above the control level across both low and high Cd concentrations, and it reached $150.8 \pm 18.6 \%$ of the control value $(P<0.01)$ at $20 \mu \mathrm{M}$. At all applied $\mathrm{Cd}$ concentrations, T-AOC relative specific activity was greater than in the control samples, showing a gradual, significant increase to $171.6 \pm 22.2 \%$ of the control value at $0.5 \mu \mathrm{M} \mathrm{Cd}$ $(P<0.01)$. After a 4 -day period of exposure to various $\mathrm{Cd}$ concentrations, this increased significantly to $410.8 \pm 66.7 \%$ of the control value at $20 \mu \mathrm{M} \mathrm{Cd}$. In contrast, the relative specific activity of CAT was lower than that of the control samples at all $\mathrm{Cd}$ concentrations, with a gradual decrease at lower Cd concentrations $(\leq 0.5 \mu \mathrm{M})$ and with a sharply significant decrease at higher Cd concentrations $(>0.5 \mu \mathrm{M})$. When the plant was exposed to $20 \mu \mathrm{M} \mathrm{Cd}$, CAT activity only amounted to $18.9 \pm 3.7 \%$ of the control value $(P<0.01)$. In addition, a correlation between the chemical form of $\mathrm{Cd}$ and Cd was observed (Figure 6). It indicated that the relationships were consistent with the logarithmic curve, in which the values of $R^{2}$ were above $0.86 . \mathrm{F}_{\mathrm{HCl}^{-}} \mathrm{Cd}$ exhibited the strongest correlation of the three chemical forms.

3.4. Lipid Peroxidation. The MDA content of the root showed an increase when the medium Cd concentration was increased from $0.1 \mu \mathrm{M}$ to $10 \mu \mathrm{M}$ and then dropped slightly at the $\mathrm{Cd}$ concentration of $20 \mu \mathrm{M}$ (Figure 7 ). That is, the MDA content had a plateau $(18.87 \mathrm{U} / \mathrm{mg})$ at $10 \mu \mathrm{M} \mathrm{Cd}$. The levels of MDA at and above $1 \mu \mathrm{M}$ Cd significantly exceeded those in the control. For example, the MDA concentration in duckweed roots exposed to $5 \mu \mathrm{M} \mathrm{Cd}$ was $15.8 \pm 1.13 \mathrm{U} / \mathrm{mg}$, whereas it was $6.17 \pm 0.93 \mathrm{U} / \mathrm{mg}$ in the control.

\section{Discussion}

4.1. Toxicity of Cd on Duckweed. Superfluous heavy metals may inhibit plant root growth and shoot growth $[4,35]$. The 

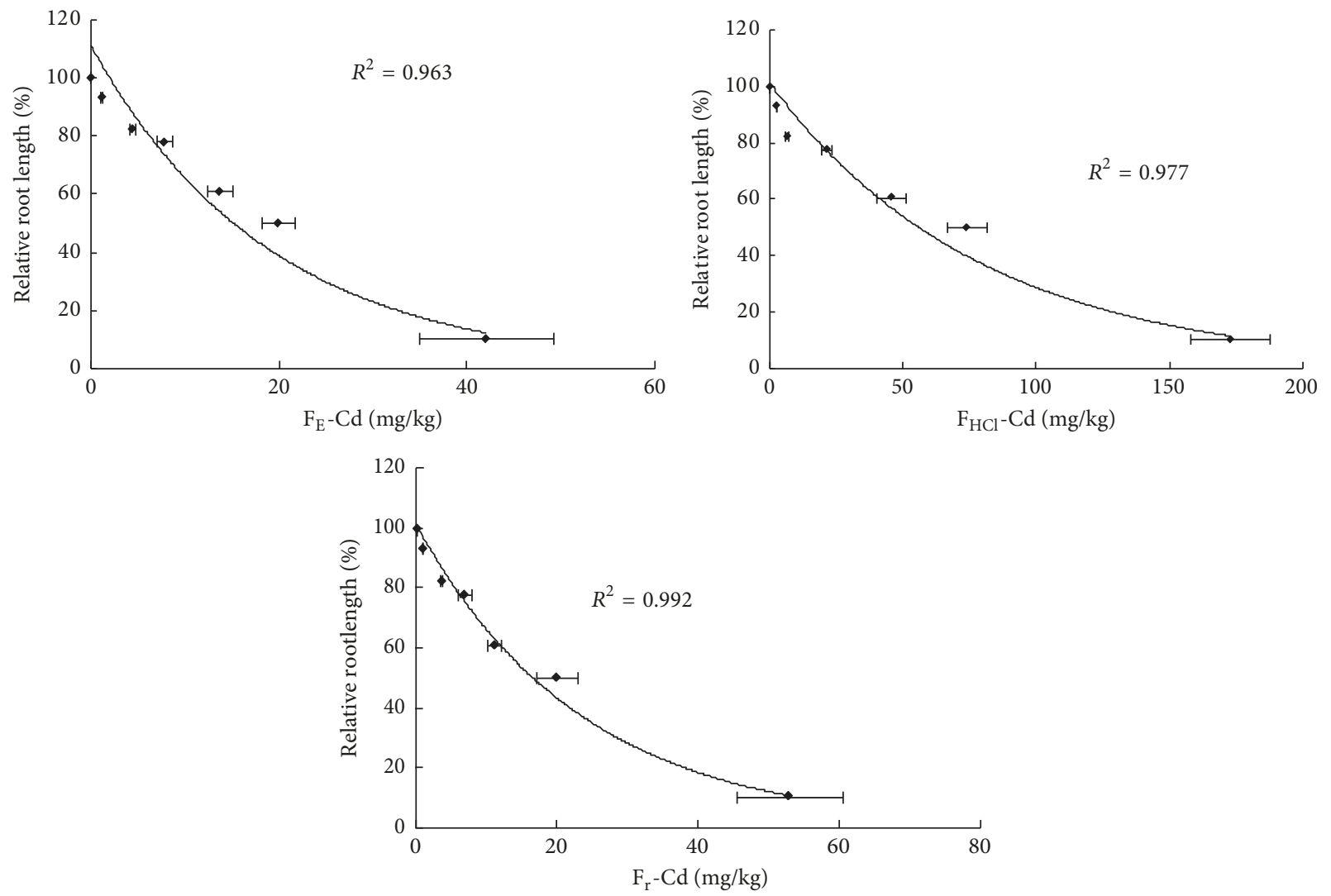

FIGURE 4: Regression between RRL (\%) and the chemical forms of Cd.
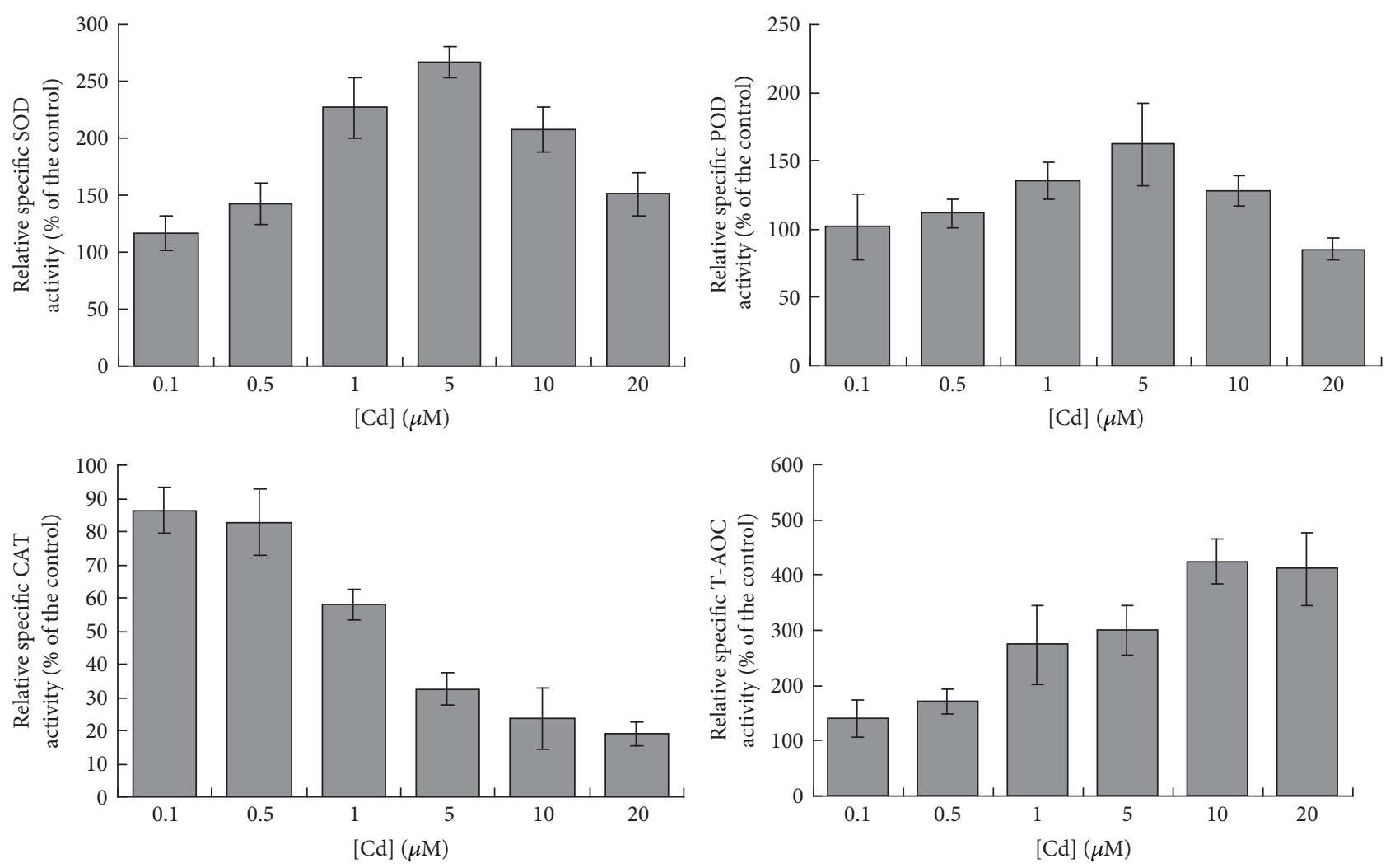

FIGURE 5: Dependence of relative specific enzyme activities of SOD, POD, CAT, and T-AOC on various Cd concentrations for 4 days. 

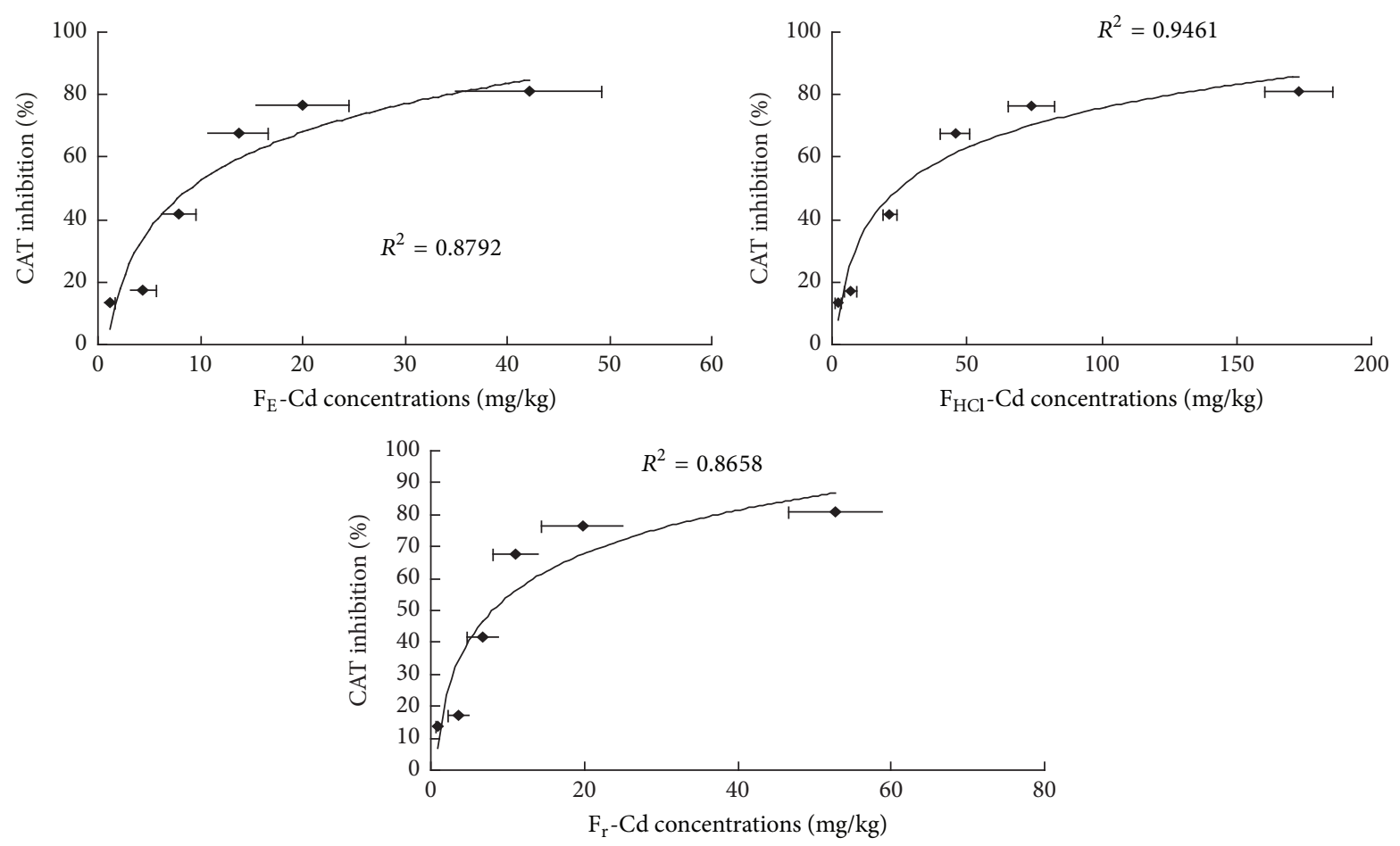

FIGURE 6: Inhibition of CAT of duckweed root as a function of Cd associated with different chemical forms.

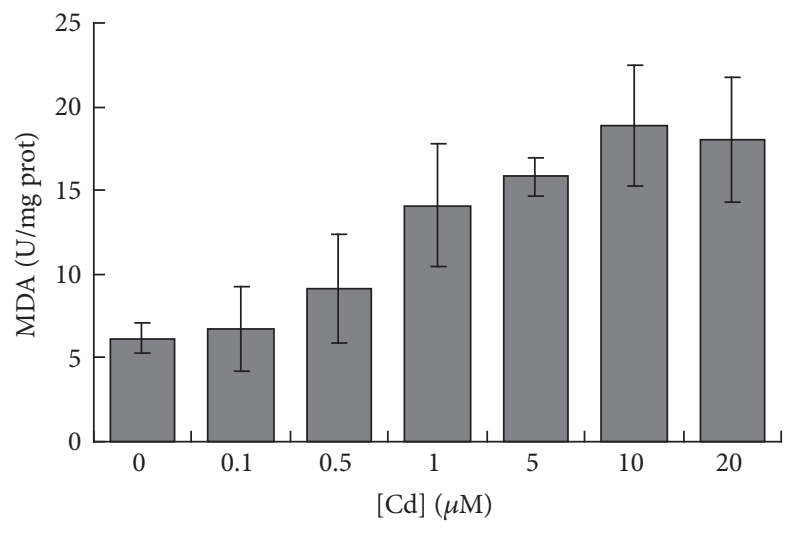

FIGURE 7: Relation of lipid peroxidation (expressed as amount of MDA) to solutions of various $\mathrm{Cd}$ concentrations.

present study found that both root elongation and frond numbers decreased with an increase in the growth medium's $\mathrm{Cd}$ concentration. Li et al. [36] found root elongation to be among the most sensitive of the growth parameters to $\mathrm{Cd}$ concentration, with an elevated Cd concentration injuring the root [37]. These observations are consistent with the present results (Figure 1). The current results suggested that the elongation of roots was significantly correlated with root Cd concentration, following the Weibull equation. Smith and Kwan [38] demonstrated high Cd toxicity in duckweed and found a Cd level of $1.7 \mu \mathrm{M}$ as $\mathrm{EC}_{50}$ (concentration for $50 \%$ of maximal effect) for the reduction in frond number after a 10day treatment. In the present results, the frond numbers were significantly decreased at the $10 \mu \mathrm{M} \mathrm{Cd}$ concentration after
4 days of treatment. Additionally, the results of the current study indicated the appearance of a hormesis phenomenon at lower $\mathrm{Cd}$ concentrations, which accords with results reported in the literature $[39,40]$.

4.2. Chemical Forms. Different chemical forms correspond to variable transport efficiencies, mobilities, and thus modes of accumulation and distribution [41, 42]. For example, high metal mobility is often associated with ethanol forms $\left(\mathrm{F}_{\mathrm{E}}\right)$, whereas metals in the form of insoluble phosphates (or those which are firmly adsorbed on the cell wall) cannot migrate freely and effectively [14]. Wu et al. [13] found higher concentrations of protein and pectates when bound by Cd in barley's Cd-resistant genotype compared with that in the Cd-sensitive genotype, implicating the chemical form of $\mathrm{Cd}$ as a factor in plant $\mathrm{Cd}$ tolerance. The current study recorded higher concentrations of $\mathrm{F}_{\mathrm{HCl}}-\mathrm{Cd}$ than $\mathrm{F}_{\mathrm{E}}-\mathrm{Cd}$ when $\mathrm{Cd}$ concentration in the solution ranged from 0.1 to $20 \mu \mathrm{M}$ (Figure 3). The implication of this is that $\mathrm{F}_{\mathrm{HCl}}{ }^{-} \mathrm{Cd}$ made contributions to $\mathrm{Cd}$ detoxification and, moreover, this was Cd's major chemical form in duckweed. In addition, with increasing $\mathrm{Cd}$, the relative contributions of $\mathrm{F}_{\mathrm{E}}-\mathrm{Cd}$ and $\mathrm{F}_{\mathrm{r}}-\mathrm{Cd}$ to total Cd content decreased, except for a peak at $0.5 \mu \mathrm{M}$. As the $\mathrm{Cd}$ concentration in the solution increased further (up to $10 \mu \mathrm{M}$ ), the $\mathrm{F}_{\mathrm{E}}-\mathrm{Cd}$ form was less prevalent than the form of $\mathrm{F}_{\mathrm{r}}$-Cd. Moreover, it became the least prevalent chemical form of $\mathrm{Cd}$ in duckweed.

These results suggest that duckweed's tolerance to high $\mathrm{Cd}$ levels can be attributed to an increase in the relative contribution of forms that are Cd-inactive, along with a decrease in the relative contribution of Cd-active forms. Moreover, $\mathrm{F}_{\mathrm{HCl}}-\mathrm{Cd}$ was depressed relative to the control, suggesting the 
action of a protection mechanism. This may also account for the higher root elongation and frond numbers at lower $\mathrm{Cd}$ concentrations in the solution. In view of this, we may conclude that it is reasonable to consider the chemical forms in which heavy metals occur to be a useful parameter for the study of metal toxicity in plants.

Ikka et al. [43] found that chemical forms can be used to assess heavy metal toxicity. The results of the present study indicated (Figure 4) a significant correlation between relative root elongation and the $\mathrm{F}_{\mathrm{E}}-\mathrm{Cd}$ and $\mathrm{F}_{\mathrm{HCl}}{ }^{-} \mathrm{Cd}$ chemical forms of $\mathrm{Cd}$, which not only suggested an association between the chemical forms and Cd toxicity but also suggested that the $\mathrm{Cd}$-sensitive fraction could be a metric for predicting $\mathrm{Cd}$ toxicity. A previous study found that the chemical form of $\mathrm{F}_{\mathrm{HCl}}-\mathrm{Cd}$ is more effective for explaining potential toxicity than is the acute toxicity [44]. Assessing the relationship between the chemical forms of heavy metals and their toxicity is therefore crucial. This study provides important evidence that $\mathrm{Cd}$ toxicity in duckweed root can be predicted by $\mathrm{F}_{\mathrm{HCl}^{-}}$ Cd.

4.3. Toxicity of Cd on Antioxidative Enzymatic Activity. Metal phytotoxicity is considered to induce OS [45, 46]. Scandalios [47] found that metals disturbed the normal balance between ROS and antioxidants in all aerobic cells, and a recently conducted study reported that increased antioxidant enzymatic activity has the capability of reducing OS for plants [45]. Under heavy metals conditions, SOD, POD, CAT, and TAOC play an important protective role against ROS-induced damage $[48,49]$. In the present study, the four analysed enzymes responded differently to Cd toxicity (Figure 5). Both SOD and POD were significantly induced at $5 \mu \mathrm{M} \mathrm{Cd}$, whereas CAT was inhibited at all tested Cd concentrations. In addition, T-AOC was induced with a gradual, significant increase after 4-day exposure to various Cd concentrations. These results are indicative of the plasticity and specificity of duckweed's antioxidative system, which is helping in reducing OS. Similar results were obtained after exposing Phragmites australis [50] and Arabidopsis thaliana [51] to $\mathrm{Cd}$, with the exception that, for P. australis, CAT activity increased. In addition, the inhibition of CAT was significantly and negatively correlated to the chemical form of $\mathrm{F}_{\mathrm{HCl}}{ }^{-} \mathrm{Cd}$ (Figure 6). This indicates that the lower CAT activities may, to some degree, result from the increased fraction of $\mathrm{F}_{\mathrm{HCl}}{ }^{-} \mathrm{Cd}$.

4.4. Toxicity of $\mathrm{Cd}$ on Lipid Peroxidation. The relationship between the toxicity of Cd and OS was also revealed by severe lipid peroxidation, as expressed with reference to MDA [52]. MDA is an indicator of OS and consequent tissue damage [53]. In the present study, MDA increased during Cd exposure in contrast with the reduction in growth of duckweed (Figure 7), which provided support for the potentially disruptive action of peroxidation lipid with respect to Cd. Zhao et al. [23] investigated that MDA content significantly increased when duckweed sp. was exposed to high concentrations of mixed metal contaminants. Singh et al. [54] found similar results when examining an aquatic plant, Bacopa monnieri. In the present study, MDA decreased slightly when exposed to high Cd $(\mu \mathrm{M})$. In the case of Spirodela polyrhiza, higher MDA levels were observed with medium exposure concentrations but reduced MDA levels were found at the highest mixed metal exposure concentrations [23], which totally agreed with our results. The researchers stated that these could act either directly or indirectly via toxic derivatives. Zhang et al. [55] found that MDA in leaves of Kandelia candel was a concentration-dependent free radical generation. In the leaves of $K$. candel, the collaboration of antioxidative enzyme activities (POD, SOD, and CAT) resulted in the MDA varieties, which are in agreement with the present results.

\section{Conclusions}

The response of duckweed roots to Cd stress is accompanied by changes in intracellular biological processes, including antioxidant enzymatic activity and the production of different chemical forms of $\mathrm{Cd}$. Taken together, our results attest to the viability of using chemical forms as a means of investigating $\mathrm{Cd}$ toxicity in duckweed. This study has confirmed that $\mathrm{F}_{\mathrm{E}^{-}}$ $\mathrm{Cd}$ is the soluble form of $\mathrm{Cd}$ and has high toxicity and that both $\mathrm{F}_{\mathrm{HCl}}-\mathrm{Cd}$ and $\mathrm{F}_{\mathrm{r}}-\mathrm{Cd}$ are insoluble and have low toxicity. Among the three chemical forms, the potentially toxic $\mathrm{Cd}$ fraction $\left(\mathrm{F}_{\mathrm{HCl}^{-}} \mathrm{Cd}\right)$ showed the highest level of accumulation. The relative $\mathrm{Cd}$ distribution showed more of the $\mathrm{Cd}$-sensitive fraction $\left(\mathrm{F}_{\mathrm{E}}-\mathrm{Cd}\right)$ than the inert fraction $\left(\mathrm{F}_{\mathrm{r}}-\mathrm{Cd}\right)$, but less $\mathrm{F}_{\mathrm{E}^{-}}$ $\mathrm{Cd}$ than $\mathrm{F}_{\mathrm{r}}$-Cd with increasing $\mathrm{Cd}$ concentration. Additionally, relative root elongation was most strongly correlated with chemical forms of Cd. The decrease in CAT activity with increasing $\mathrm{Cd}$ concentration and in the activities of POD and SOD at high Cd concentrations indicates that $\mathrm{Cd}$ concentration influences the antioxidant enzyme system. As a result of a high sensitivity to Cd, CAT could be a biological indicator of Cd toxicity in duckweed roots. In conclusion, the current study has provided important evidence that illuminates the mechanism of Cd toxicity in duckweed.

\section{Conflicts of Interest}

The authors declare that they have no conflicts of interest.

\section{Acknowledgments}

This study was supported by the National Natural Science Foundation of China (Grants nos. 51109109 and 41505113) and the Priority Academic Program Development of Jiangsu Higher Education Institutions. The authors extend their thanks to the Jiangsu Engineering Technology Research Center of Environmental Cleaning Materials.

\section{References}

[1] G. Fellet, M. Marmiroli, and L. Marchiol, "Elements uptake by metal accumulator species grown on mine tailings amended with three types of biochar," Science of the Total Environment, vol. 468-469, pp. 598-608, 2014.

[2] A. Wagner and M. Kaupenjohann, "Suitability of biochars (pyro- and hydrochars) for metal immobilization on former sewage-field soils," European Journal of Soil Science, vol. 65, no. 1, pp. 139-148, 2014. 
[3] P. Modlitbová, K. Novotný, P. Pořízka et al., "Comparative investigation of toxicity and bioaccumulation of Cd-based quantum dots and Cd salt in freshwater plant Lemna minor L.," Ecotoxicology and Environmental Safety, vol. 147, pp. 334-341, 2018.

[4] J. Gao, L. Sun, X. Yang, and J.-X. Liu, “Transcriptomic Analysis of Cadmium Stress Response in the Heavy Metal Hyperaccumulator Sedum alfredii Hance," PLoS ONE, vol. 8, no. 6, Article ID e64643, 2013.

[5] J. Xin, B. Huang, Z. Yang, J. Yuan, and Y. Zhang, "Comparison of cadmium subcellular distribution in different organs of two water spinach (Ipomoea aquatica Forsk.) cultivars," Plant and Soil, vol. 372, no. 1-2, pp. 431-444, 2013.

[6] Y. Li, H.-D. Pang, L.-Y. He, Q. Wang, and X.-F. Sheng, "Cd immobilization and reduced tissue $\mathrm{Cd}$ accumulation of rice (Oryza sativa wuyun-23) in the presence of heavy metalresistant bacteria," Ecotoxicology and Environmental Safety, vol. 138, pp. 56-63, 2017.

[7] L. Wan and H. Zhang, "Cadmium toxicity: effects on cytoskeleton, vesicular trafficking and cell wall construction," Plant Signaling and Behavior, vol. 7, no. 3, pp. 345-348, 2012.

[8] N. Luo, X. Li, A. Y. Chen et al., "Does arbuscular mycorrhizal fungus affect cadmium uptake and chemical forms in rice at different growth stages?" Science of the Total Environment, vol. 599-600, pp. 1564-1572, 2017.

[9] J. Wang, L. Su, J. Yang et al., "Comparisons of cadmium subcellular distribution and chemical forms between low-Cd and high-Cd accumulation genotypes of watercress (Nasturtium officinale L. R. Br.)," Plant and Soil, vol. 396, no. 1-2, pp. 325337, 2015.

[10] H.-Y. Lai, "Subcellular distribution and chemical forms of cadmium in Impatiens walleriana in relation to its phytoextraction potential," Chemosphere, vol. 138, pp. 370-376, 2015.

[11] J. L. W. Lwalaba, G. Zvobgo, M. Mwamba, I. M. Ahmed, R. P. M. Mukobo, and G. Zhang, "Subcellular distribution and chemical forms of $\mathrm{Co} 2+$ in three barley genotypes under different $\mathrm{Co} 2+$ levels," Acta Physiologiae Plantarum, vol. 39, no. 4, article no. 102, 2017.

[12] A. Yin, Z. Yang, S. Ebbs, J. Yuan, J. Wang, and J. Yang, "Effects of phosphorus on chemical forms of Cd in plants of four spinach (Spinacia oleracea L.) cultivars differing in Cd accumulation," Environmental Science and Pollution Research, vol. 23, no. 6, pp. 5753-5762, 2016.

[13] F.-B. Wu, J. Dong, Q. Q. Qiong, and G.-P. Zhang, "Subcellular distribution and chemical form of $\mathrm{Cd}$ and $\mathrm{Cd}-\mathrm{Zn}$ interaction in different barley genotypes," Chemosphere, vol. 60, no. 10, pp. 1437-1446, 2005.

[14] T. M. Mwamba, L. Li, R. A. Gill et al., "Differential subcellular distribution and chemical forms of cadmium and copper in Brassica napus," Ecotoxicology and Environmental Safety, vol. 134, pp. 239-249, 2016.

[15] X. Xu, S. Zhang, J. Xian et al., "Subcellular distribution, chemical forms and thiol synthesis involved in cadmium tolerance and detoxification in," International Journal of Phytoremediation, 2017.

[16] M. V. Pérez-Chaca, M. Rodríguez-Serrano, A. S. Molina et al., "Cadmium induces two waves of reactive oxygen species in Glycine max (L.) roots," Plant, Cell \& Environment, vol. 37, no. 7, pp. 1672-1687, 2014.

[17] J. Razinger, M. Dermastia, J. D. Koce, and A. Zrimec, "Oxidative stress in duckweed (Lemna minor L.) caused by short-term cadmium exposure," Environmental Pollution, vol. 153, no. 3, pp. 687-694, 2008.

[18] H. Rui, C. Chen, X. Zhang, Z. Shen, and F. Zhang, "Cd-induced oxidative stress and lignification in the roots of two Vicia sativa L. varieties with different Cd tolerances," Journal of Hazardous Materials, vol. 301, pp. 304-313, 2016.

[19] A. X. Da Rosa Corrêa, L. R. Rörig, M. A. Verdinelli, S. Cotelle, J.F. Férard, and C. M. Radetski, "Cadmium phytotoxicity: Quantitative sensitivity relationships between classical endpoints and antioxidative enzyme biomarkers," Science of the Total Environment, vol. 357, no. 1-3, pp. 120-127, 2006.

[20] E. Landolt, "The family of Lemnaceae-a monographic study," in Biosystematic investigations in the family of duckweeds (Lemnaceae), vol. 2, Veröffentlichungen des Geobotanischen Institutes, Stiftung Rübel, ETH. 71, Zürich, 1986.

[21] Z. Ali, H. Waheed, A. G. Kazi, A. Hayat, and M. Ahmad, "Duckweed: An Efficient Hyperaccumulator of Heavy Metals in Water Bodies," Plant Metal Interaction: Emerging Remediation Techniques, pp. 411-429, 2015.

[22] M. S. Al-Khafaji, F. H. Al-Ani, and A. F. Ibrahim, "Removal of some heavy metals from industrial wastewater by Lemmna minor," KSCE Journal of Civil Engineering, pp. 1-6, 2017.

[23] Z. Zhao, H. Shi, X. Kang et al., "Inter- and intra-specific competition of duckweed under multiple heavy metal contaminated water," Aquatic Toxicology, vol. 192, pp. 216-223, 2017.

[24] S. Y. Tatar, E. Obek, and N. Cikcikoglu Yildirim, "Antioxidant Response in Duckweed After Exposure to Secondary Effluent from Municipal Wastewater Treatment Plant, Elazığ, Turkey," Bulletin of Environmental Contamination and Toxicology, vol. 99, no. 3, pp. 399-404, 2017.

[25] H. E. Ensley, J. T. Barber, M. A. Polito, and A. I. Oliver, "Toxicity and metabolism of 2,4-dichlorophenol by the aquatic angiosperm Lemna gibba," Environmental Toxicology and Chemistry, vol. 13, no. 2, pp. 325-331, 1994.

[26] P. Wang, D. Zhou, T. B. Kinraide et al., "Cell membrane surface potential $(\psi 0)$ plays a dominant role in the phytotoxicity of copper and arsenate," Plant Physiology, vol. 148, no. 4, pp. 21342143, 2008.

[27] G. J. Taylor, K. J. Stadt, and M. R. T. Dale, "Modelling the phytotoxicity of aluminum, cadmium, copper, manganese, nickel, and zinc using the Weibull frequency distribution," Botany, vol. 69, no. 2, pp. 359-367, 1991.

[28] H. M. Wu, F. L. Li, H. Q. Mou, and H. Zhang, "Analysis of heavy metal fractions in plants by two steps sequential extraction procedure," Environmental Science Technology (in Chinese), vol. 35, no. 7, pp. 133-137, 2012.

[29] Y. Nakano and K. Asada, "Hydrogen peroxide is scavenged by ascorbate-specific peroxidase in spinach chloroplasts," Plant \& Cell Physiology (PCP), vol. 22, no. 5, pp. 867-880, 1981.

[30] F. Tao, M. Zhang, and H.-Q. Yu, "Effect of vacuum cooling on physiological changes in the antioxidant system of mushroom under different storage conditions," Journal of Food Engineering, vol. 79, no. 4, pp. 1302-1309, 2007.

[31] C. Beauchamp and I. Fridovich, "Superoxide dismutase: Improved assays and an assay applicable to acrylamide gels," Analytical Biochemistry, vol. 44, no. 1, pp. 276-287, 1971.

[32] H. Aebi, "Catalase in vitro," Methods in Enzymology, vol. 105, pp. 121-126, 1984.

[33] C. Ortega-Villasante, R. Rellán-Álvarez, F. F. Del Campo, R. O. Carpena-Ruiz, and L. E. Hernández, "Cellular damage induced by cadmium and mercury in Medicago sativa," Journal of Experimental Botany, vol. 56, no. 418, pp. 2239-2251, 2005. 
[34] D.-Q. Sun, A.-W. Li, J. Li et al., "Changes of lipid peroxidation in carbon disulfide-treated rat nerve tissues and serum," ChemicoBiological Interactions, vol. 179, no. 2-3, pp. 110-117, 2009.

[35] M. Kopyra and E. A. Gwóźdź, "Nitric oxide stimulates seed germination and counteracts the inhibitory effect of heavy metals and salinity on root growth of Lupinus luteus," Plant Physiology and Biochemistry, vol. 41, no. 11-12, pp. 1011-1017, 2003.

[36] H. S. Li, Q. Sun, and S. J. Zhao, The Physiological and Physiochemical Experiment Theory and Technique, Higher Education Publishing Company, Beijing, China, 2000.

[37] T. Lambrechts, G. Lequeue, G. Lobet, B. Godin, C. L. Bielders, and S. Lutts, "Comparative analysis of $\mathrm{Cd}$ and $\mathrm{Zn}$ impacts on root distribution and morphology of Lolium Perenne and Trifolium repens: Implications for phytostabilization," Plant and Soil, vol. 376, no. 1, pp. 229-244, 2014.

[38] S. Smith and M. K. H. Kwan, "Use of aquatic macrophytes as a bioassay method to assess relative toxicity, uptake kinetics and accumulated forms of trace metals," Hydrobiologia, vol. 188-189, no. 1, pp. 345-351, 1989.

[39] E. J. Calabrese, "Hormesis: Principles and Applications for Pharmacology and Toxicology," American Journal of Pharmacology and Toxicology, vol. 3, no. 1, pp. 59-71, 2008.

[40] B. Huang, J. Xin, H. Dai, W. Zhou, and L. Peng, "Identification of low-Cd cultivars of sweet potato (Ipomoea batatas (L.) Lam.) after growing on Cd-contaminated soil: uptake and partitioning to the edible roots," Environmental Science and Pollution Research, vol. 22, no. 15, pp. 11813-11821, 2015.

[41] Y. Zhao, J. Wu, D. Shang et al., "Subcellular distribution and chemical forms of cadmium in the edible seaweed, Porphyra yezoensis," Food Chemistry, vol. 168, pp. 48-54, 2015.

[42] A. G. Caporale and A. Violante, "Chemical Processes Affecting the Mobility of Heavy Metals and Metalloids in Soil Environments," Current Pollution Reports, vol. 2, no. 1, pp. 15-27, 2016.

[43] T. Ikka, T. Ogawa, D. Li, S. Hiradate, and A. Morita, "Effect of aluminum on metabolism of organic acids and chemical forms of aluminum in root tips of Eucalyptus camaldulensis Dehnh.," Phytochemistry, vol. 94, pp. 142-147, 2013.

[44] Q. Qiu, Y. Wang, Z. Yang, and J. Yuan, "Effects of phosphorus supplied in soil on subcellular distribution and chemical forms of cadmium in two Chinese flowering cabbage (Brassica parachinensis L.) cultivars differing in cadmium accumulation," Food and Chemical Toxicology, vol. 49, no. 9, pp. 2260-2267, 2011.

[45] M. Shahid, B. Pourrut, C. Dumat, M. Nadeem, M. Aslam, and E. Pinelli, "Heavy-metal-induced reactive oxygen species: Phytotoxicity and physicochemical changes in plants," Reviews of Environmental Contamination and Toxicology, vol. 232, pp. 144, 2014.

[46] T. M. Mwamba, S. Ali, B. Ali et al., "Interactive effects of cadmium and copper on metal accumulation, oxidative stress, and mineral composition in Brassica napus," International Journal of Environmental Science and Technology, vol. 13, no. 9, pp. 21632174, 2016.

[47] J. G. Scandalios, "The rise of ROS," Trends in Biochemical Sciences, vol. 27, no. 9, pp. 483-486, 2002.

[48] Y. Liang, Q. Chen, Q. Liu, W. Zhang, and R. Ding, "Exogenous silicon ( $\mathrm{Si}$ ) increases antioxidant enzyme activity and reduces lipid peroxidation in roots of salt-stressed barley (Hordeum vulgare L.)," Journal of Plant Physiology, vol. 160, no. 10, pp. 11571164, 2003.
[49] C. M. André, Y. Larondelleb, and D. Evers, "Dietary antioxidants and oxidative stress from a human and plant perspective: A review," Current Nutrition and Food Science, vol. 6, no. 1, pp. 2-12, 2010.

[50] M. A. Iannelli, F. Pietrini, L. Fiore, L. Petrilli, and A. Massacci, "Antioxidant response to cadmium in Phragmites australis plants," Plant Physiology and Biochemistry, vol. 40, no. 11, pp. 977-982, 2002.

[51] W. Maksymiec and Z. Krupa, "The effects of short-term exposition to $\mathrm{Cd}$, excess $\mathrm{Cu}$ ions and jasmonate on oxidative stress appearing in Arabidopsis thaliana," Environmental and Experimental Botany, vol. 57, no. 1-2, pp. 187-194, 2006.

[52] U.-H. Cho and N.-H. Seo, "Oxidative stress in Arabidopsis thaliana exposed to cadmium is due to hydrogen peroxide accumulation," Journal of Plant Sciences, vol. 168, no. 1, pp. 113120, 2005.

[53] V. Arbona, V. Flors, J. Jacas, P. García-Agustín, and A. GómezCadenas, "Enzymatic and non-enzymatic antioxidant responses of Carrizo citrange, a salt-sensitive citrus rootstock, to different levels of salinity," Plant \& Cell Physiology (PCP), vol. 44, no. 4, pp. 388-394, 2003.

[54] S. Singh, S. Eapen, and S. F. D'Souza, "Cadmium accumulation and its influence on lipid peroxidation and antioxidative system in an aquatic plant, Bacopa monnieri L.," Chemosphere, vol. 62, no. 2, pp. 233-246, 2006.

[55] F.-Q. Zhang, Y.-S. Wang, Z.-P. Lou, and J.-D. Dong, "Effect of heavy metal stress on antioxidative enzymes and lipid peroxidation in leaves and roots of two mangrove plant seedlings (Kandelia candel and Bruguiera gymnorrhiza)," Chemosphere, vol. 67, no. 1, pp. 44-50, 2007. 

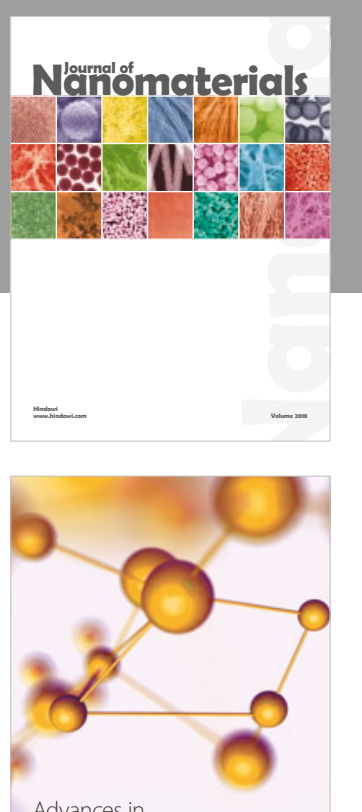

Physical Chemistry
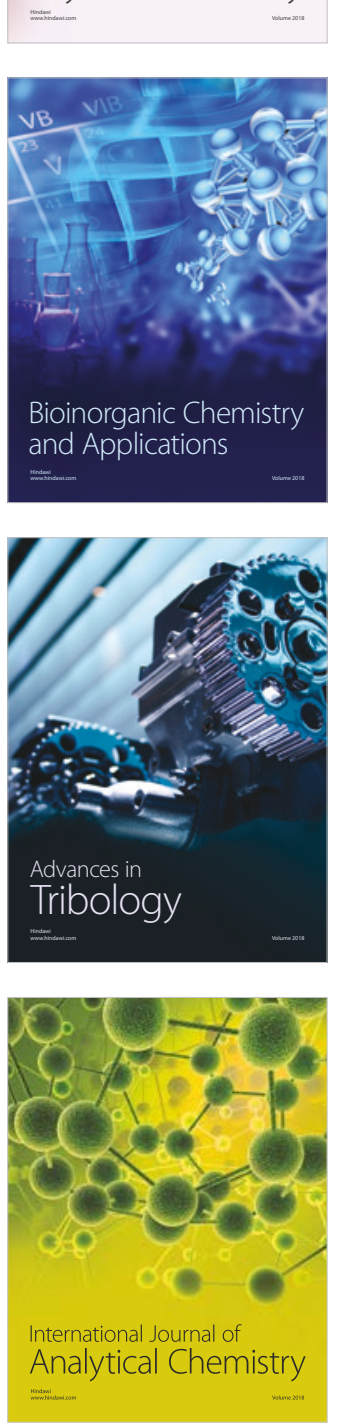

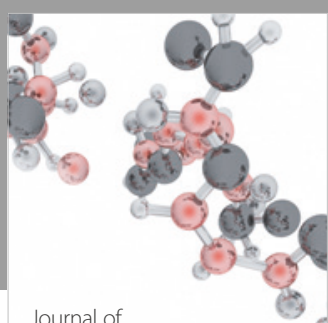

Analytical Methods

in Chemistry

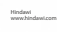

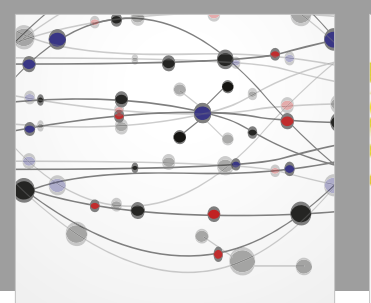

The Scientific World Journal

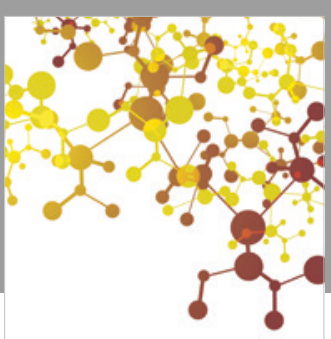

Journal of

Applied Chemistry
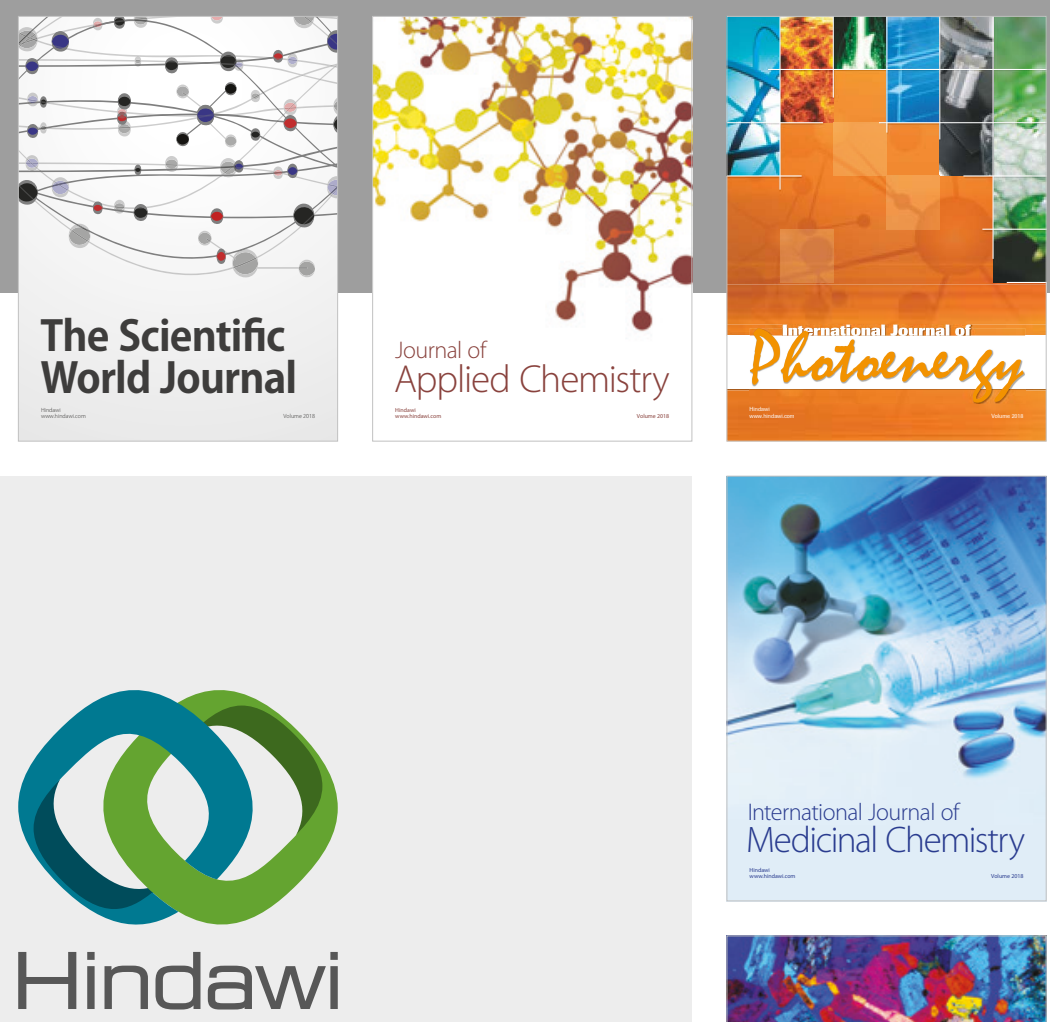

Submit your manuscripts at

www.hindawi.com
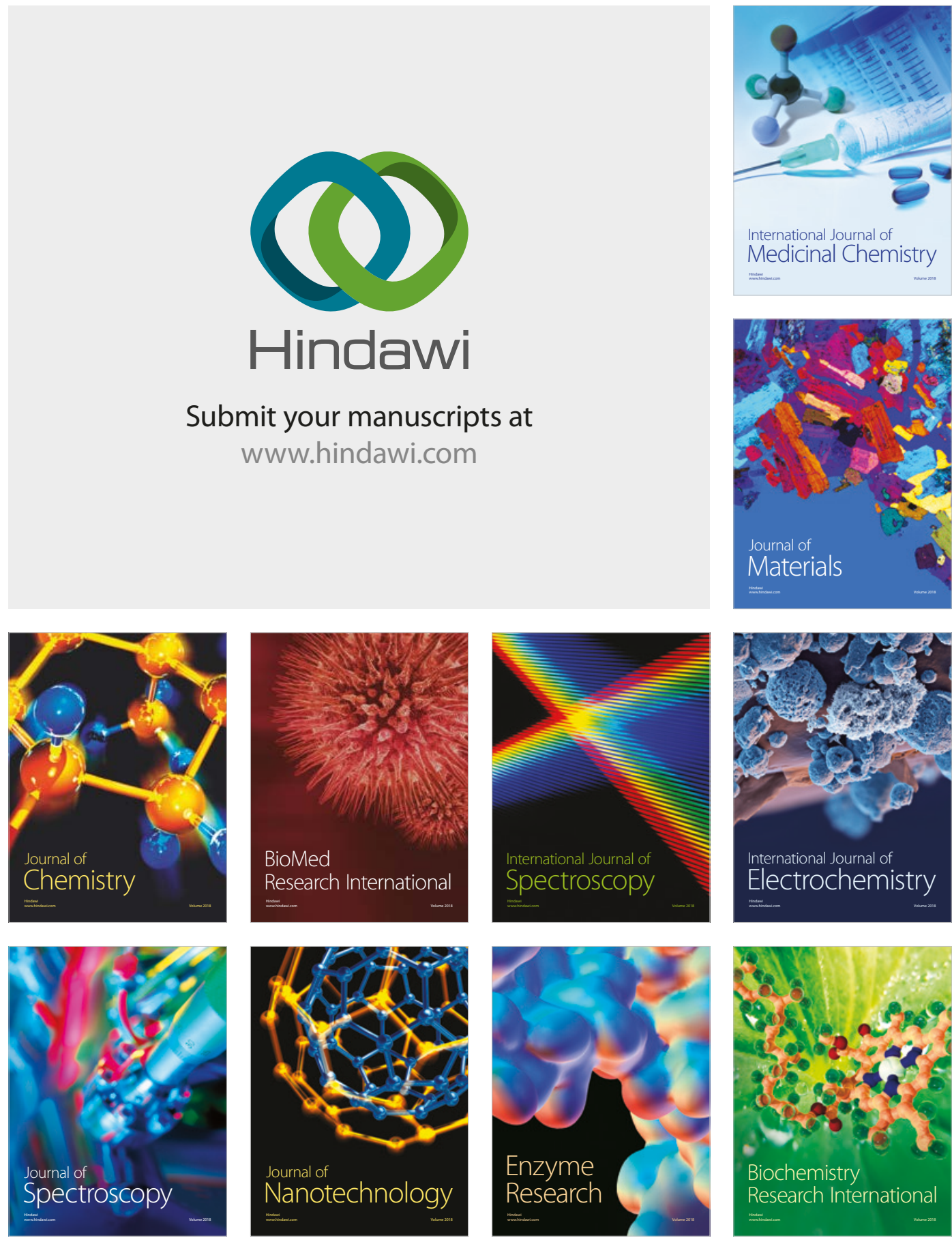
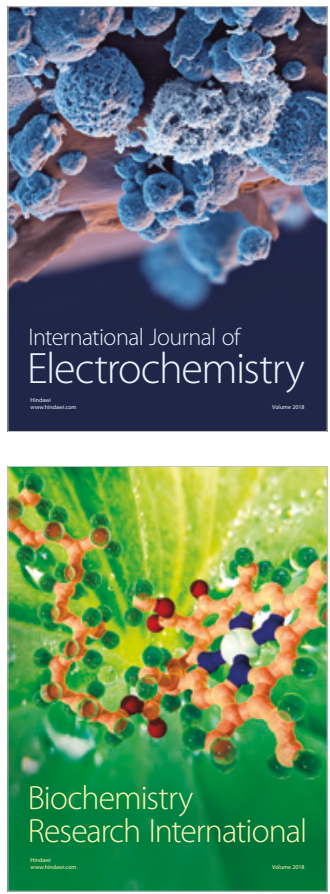